\title{
The Contrasting Role of Nasopharyngeal Angiotensin Converting Enzyme 2 (ACE2) Expression in SARS-CoV-2 Infection: A Cross-Sectional Study of People Tested for COVID-19 in British Columbia
}

Authors: Aidan M. Nikiforuk ${ }^{1,4 *}$ (MSc.), Kevin S. Kuchinski ${ }^{1,2 *}$ (BSc.), David D.W. Twa ${ }^{2,3 *}$ (PhD), Christine D. Lukac ${ }^{1}$ (MPH), Hind Sbihi ${ }^{1,4}(\mathrm{PhD})$, C. Andrew Basham ${ }^{1,4}$ (MSc.), Christian Steidl $^{3}$ (MD), Natalie A. Prystajecky ${ }^{1,2}(\mathrm{PhD})$, Agatha N. Jassem ${ }^{1,2}$ (PhD), Mel Krajden ${ }^{1,2}$ (MD), David M, Patrick $^{1,4}(\mathrm{MD})$ and Inna Sekirov ${ }^{1,2}(\mathrm{PhD})$.

*these authors contributed equally to the work.

${ }^{1}$ British Columbia Centre for Disease Control, Vancouver, V5Z 4R4, British Columbia, Canada ${ }^{2}$ Department of Pathology and Laboratory Medicine, University of British Columbia, Vancouver, V6T 1Z4, British Columbia, Canada

${ }^{3}$ British Columbia Cancer Research Centre, Vancouver, V5Z 1L3, British Columbia, Canada ${ }^{4}$ School of Population and Public Health, University of British Columbia, Vancouver, V6T 1Z4, British Columbia, Canada

Corresponding Author: Dr. Inna Sekirov MD/ PhD, British Columbia Centre for Disease Control, Vancouver, British Columbia, Canada, V5Z 4R4 and Department of Pathology and Laboratory Medicine, University of British Columbia, Vancouver, British Columbia, Canada, V6T $1 Z 4$. email: inna.sekirov@bccdc.ca 


\section{Summary}

Background

Angiotensin converting enzyme 2 (ACE2) serves as the host receptor for SARS-CoV-2, with a critical role in viral infection. We aim to understand population level variation of nasopharyngeal ACE2 expression in people tested for COVID-19 and the relationship between ACE2 expression and SARS-CoV-2 viral RNA load, while adjusting for expression of the complementary protease, Transmembrane serine protease 2 (TMPRSS2), soluble ACE2, age, and biological sex.

Methods

A cross-sectional study of $n=424$ participants aged 1-104 years referred for COVID-19 testing was performed in British Columbia, Canada. Participants who tested negative or positive for COVID-19 were matched by age and biological sex. Viral and host gene expression was measured by quantitative reverse-transcriptase polymerase chain reaction. Bivariate analysis and multiple linear regression were performed to understand the role of nasopharyngeal $A C E 2$ expression in SARS-CoV-2 infection. The ACE2 gene was targeted to measure expression of transmembrane and soluble transcripts.

\section{Findings}

Analysis shows no association between age and nasopharyngeal ACE2 expression in those who tested negative for COVID-19 (P=0.092). Mean expression of transmembrane $(\mathrm{P}=1 \cdot 2 \mathrm{e}-4)$, soluble ACE2 $(\mathrm{P}<0 \cdot 0001)$ and TMPRSS2 ( $\mathrm{P}<0 \cdot 0001)$ differed between COVID-19negative and -positive groups. In bivariate analysis of COVID-19-positive participants, expression of transmembrane $A C E 2$ positively correlated with SARS-CoV-2 RNA viral load

$72(\mathrm{P}<0 \cdot 0001)$, expression of soluble $A C E 2$ negatively correlated $(\mathrm{P}<0 \cdot 0001)$, and no correlation

73 was found with TMPRSS2 $(P=0 \cdot 694)$. Multivariable analysis showed that the greatest viral RNA

74 loads were observed in participants with high transmembrane $A C E 2$ expression $(B=0 \cdot 886$,

$7595 \%$ CI:[0.596 to 1.18]), while expression of soluble ACE2 may protect against high viral RNA

76 load in the upper respiratory tract $(B=-0 \cdot 0990,95 \% \mathrm{CI}:[-0 \cdot 176$ to $-0 \cdot 0224])$. 
medRxiv preprint doi: https://doi.org/10.1101/2020.11.23.20237206; this version posted November 27, 2020. The copyright holder for this preprint (which was not certified by peer review) is the author/funder, who has granted medRxiv a license to display the preprint in perpetuity.

It is made available under a CC-BY-NC-ND 4.0 International license .

\section{Interpretation}

Nasopharyngeal ACE2 expression plays a dual, contrasting role in SARS-CoV-2 infection of the upper respiratory tract. Transmembrane ACE2 positively correlates, while soluble ACE2 negatively correlates with viral RNA load after adjusting for age, biological sex and expression of TMPRSS2.

\section{Funding}

This project (COV-55) was funded by Genome British Columbia as part of their COVID19 rapid response initiative.

\section{Research in Context}

\section{Evidence before this study}

We conducted a MEDLINE ${ }^{\circledR}$ search using the MeSH topic terms: "angiotensin converting enzyme 2 expression" and "SARS" and "age", restricting the search to Englishlanguage reports published from January $1^{\text {st }}, 2020$. The search returned $n=98$ articles, eightyeight of which reported primary research; these were further filtered by the MeSH qualifiers "epidemiology" and "virology" to provide $n=43$ articles. Search results were further restricted to the MeSH headings: age, virus replication, host pathogen interactions, nasal mucosa, RNA viral load and real-time polymerase chain reaction, which returned $n=24$ results. We read through the abstracts of these twenty-four papers and manually selected $n=4$ for full review. This review provided evidence that $A C E 2$ expression is greater in the upper respiratory tract than the lower respiratory tract, when measured by single-cell RNA sequencing, immunohistochemistry and high-sensitivity RNA in-situ mapping. In the upper airway, ACE2 mRNA abundance closely correlates with protein concentration. A reverse genetics study demonstrated that a variable SARS-CoV-2 infection gradient occurs in the respiratory tract, with highest viral loads expected in the upper airway. In several patient cohorts, upper respiratory expression of $A C E 2$ was significantly increased in those who smoke, in this analysis multivariable adjustment of age suggested limited confounding. 


\section{Added Value of this study}

110 We measured ACE2 expression in the context of COVID-19 testing to investigate the role 111 of nasopharyngeal ACE2 in SARS-CoV-2 infection. Our findings support previous work: the 112 strong correlation we observe between nasopharyngeal ACE2 expression and SARS-CoV-2 load 113 also suggests an infection gradient across the human airway. Greater viral loads are expected in 114 tissue with high transmembrane ACE2 expression. No observed relationship between age and 115 nasopharyngeal $A C E 2$ in COVID-19-negative participants suggests that upper airway $A C E 2$ 116 expression is independent of the RAAS pathway. We are the first to measure endogenous 117 expression of soluble ACE2 in the upper airway of people tested for COVID-19 and include this 118 measure in multivariable analysis. Importantly, nasopharyngeal expression of soluble ACE2 119 negatively correlates with viral RNA load, inferring a protective role at the population level.

Considering all available evidence, ACE2 may play a dual, contrasting role in SARS-

123 CoV-2 infection of the upper airway. Expression of transmembrane ACE2 positively correlates

124 with SARS-CoV-2 RNA load, while expression of soluble ACE2 shows a negative association.

125 Expression of nasopharyngeal ACE2 does not seem to correlate with age, as would be expected

126 in the lower respiratory tract. Risk factors such as smoking may affect the baseline risk of high

127 SARS-CoV-2 RNA loads in those infected. Factors associated with endogenous nasopharyngeal 128 expression of soluble ACE2 require further investigation.

\section{Introduction}

In December 2019, clusters of viral pneumonia were reported in Wuhan, China. A novel

132 highly pathogenic human coronavirus was isolated and named severe acute respiratory syndrome 133 coronavirus 2 (SARS-CoV-2), the etiological agent of coronavirus disease (COVID-19). ${ }^{1}$ SARS-

134 CoV-2 utilizes the same host receptor and protease for cell entry as the human coronaviruses 135 SARS-CoV and HCoV-NL63. The receptor angiotensin converting enzyme 2 (ACE2) mediates 136 cellular entry, while transmembrane serine protease 2 (TMPRSS2) serves as a complementary 137 host factor. ${ }^{2,3}$ In human physiology, ACE2 has a cardiovascular protective and anti-inflammatory 138 role, as a constituent of the renin-angiotensin-aldosterone-system (RAAS). ${ }^{4}$ Interestingly, 
expression of $A C E 2$ in the nasopharyngeal tract exceeds that in alveolar tissue, explaining initiation of SARS-CoV-2 infection in the upper respiratory tract. ${ }^{5}$ Transcription of ACE2

141 produces at least two dominant mRNA transcripts responsible for translation into soluble and

142 membrane-bound protein isoforms. ${ }^{6}$ Although the transmembrane isoform has been shown to be

143 crucial for viral entry into host cells, the role of soluble ACE2 remains uncharacterized, though

144 some evidence exists that it protects against SARS-CoV-2 infection. ${ }^{7,8}$ Transmembrane serine

145 protease 2 (TMPRSS2) contributes to SARS-CoV-2 cell entry by cleaving the viral spike protein

146 into a conformational form necessary for membrane fusion. ${ }^{2}$ Unlike ACE2, TMPRSS2 expression

147 occurs more stably across upper airway tissue and alternative enzymes such as cathepsin B/L

148 may perform its role in viral infection interchangeably. ${ }^{5}$ To understand the importance of $A C E 2$

149 expression in SARS-CoV-2 infection, we performed a cross-sectional study of people tested for

150 COVID-19 in British Columbia, Canada. The study aims to investigate the relationship between

151 i) nasopharyngeal expression of $A C E 2$ and age in COVID-19-negative participants, ii)

152 nasopharyngeal expression of host genes by COVID-19 test result and iii) nasopharyngeal

153 expression of transmembrane ACE2 and viral RNA load in those who tested COVID-19-positive

154 adjusting for age, biological sex, expression of soluble ACE2 and TMPRSS2. Characterizing

155 expression of nasopharyngeal ACE2 in a large group of participants tested for COVID-19 will

156 increase our knowledge of host genes involved in viral infection and may allow for assessment

157 of baseline risk.

\section{Methods}

Study Design and Participants

161 We performed cross-sectional sampling of people tested for COVID-19 at the British

162 Columbia Center for Disease Control Public Health Laboratory (BCCDC-PHL) from 24/3/2020-

$1639 / 5 / 2020$. At the time of sampling, provincial health guidelines required a clinical indication for

164 referral of a COVID-19 test. Inclusion criteria were applied to select study participants whose

165 diagnostic specimens were: tested centrally at the BCCDC-PHL, collected by nasopharyngeal

166 swab, the first test administered by provincial health number, suspended in Hologic Aptima ${ }^{\mathrm{TM}}$

167 media, negative for concurrent Influenza A, B or Respiratory syncytia virus infection, stored at -

$16880^{\circ} \mathrm{C}$ following RNA extraction and for whom host gene expression was successfully measured

169 by quantitative reverse-transcriptase polymerase chain reaction (qRT-PCR). People meeting the 
170 inclusion criteria $(n=444)$, were excluded $(n=16)$ if samples had a SARS-CoV-2 E gene cycle

171 threshold $(\mathrm{Ct})$ value of $>=38$ by qRT-PCR. COVID-19-positive cases $(\mathrm{n}=212)$ were matched in a

172 1:1 ratio with those that tested negative for COVID-19 by age and biological sex (Figure S1).

173 Ethical approval for the study was obtained from the University of British Columbia

174 human ethics board (H20-01110). Demographic variables of age and biological sex were drawn

175 from public health laboratory data. Laboratory methods were performed in a College of

176 American Pathologists accredited laboratory with externally validated qRT-PCR assays. ${ }^{9-12}$

Procedures

Nasopharyngeal samples collected in Hologic Aptima ${ }^{\mathrm{TM}}$ media were stored at $4^{\circ} \mathrm{C}$ before RNA extraction using the Viral RNA isolation kit on the MagMAX-96 ${ }^{\mathrm{TM}}$ platform (ThermoFisher). ${ }^{13}$

Host and viral gene targets were assayed by qRT-PCR on the Applied Biosystems 7500

183 Real-Time PCR platform using TaqMan FastVirus 1-step polymerase (ThermoFisher). Total reaction volumes equaled $20 u$, with $5 u$ l of RNA template, $1 u$ l of 20x primer/probe, $5 u 1$ Fast Virus and $9 u l$ of nuclease free water per reaction. Cycling conditions were set to: $50^{\circ} \mathrm{C}$ for 5 minutes, $95^{\circ} \mathrm{C}$ for 20 seconds followed by 40 cycles of $95^{\circ} \mathrm{C}$ for 15 seconds and $60^{\circ} \mathrm{C}$ for 1 minute. A multiplex qRT-PCR reaction targeting SARS-CoV-2 envelope (E) and host

188 ribonuclease $\mathrm{P}$ (RNaseP) was used to diagnosis acute viral infection by presence of viral RNA. ${ }^{14}$

189 Expression of RNaseP was used to ensure sample quality and control for sampling variation. ${ }^{14}$

190 Participants were diagnosed as COVID-19 positive with an E gene $\mathrm{Ct}$ value of <38. The E gene

$191 \mathrm{Ct}$ values were transformed to genome equivalents per millilitre by making a 5-fold, 1:10

192 standard curve of SARS-CoV-2 synthetic RNA- MN908947.3 (Twist Bioscience) (Table S1).

193 Commercially available primer probe sets were used to amplify the host gene targets

194 TMPRSS2 ${ }^{12}$ (Hs00237175_m1) (ThermoFisher) and ACE2 ${ }^{10}$ (Hs01085333_m1,

195 HS01085340_m1) by multiplex qRT-PCR with a glyceraldehyde 3-phosphate dehydrogenase

$196(G A P D H)$ control $^{11}$ (Hs02758991_g1) (ThermoFisher). Relative gene expression was calculated

197 between TMPRSS2, ACE2 and GAPDH using the $2^{-\Delta \Delta \mathrm{Ct}}$ method. ${ }^{15}$ Transmembrane ACE2 was

198 defined from the Hs01085333_m1 (ThermoFisher) gene target, which exon spans the

199 transmembrane domain. Soluble ACE2 was defined as absolute relative expression between the

200 Hs01085333_m1 (ThermoFisher) and HS01085340_m1 (ThermoFisher) gene targets (Figure 
medRxiv preprint doi: https://doi.org/10.1101/2020.11.23.20237206; this version posted November $27,2020$. The copyright holder for this preprint (which was not certified by peer review) is the author/funder, who has granted medRxiv a license to display the preprint in perpetuity.

It is made available under a CC-BY-NC-ND 4.0 International license .

201

202

203

204

205

206

207

208

209

210

211

212

213

214

215

216

217

218

219

220

221

222

223

224

225

226

227

228

229

230

231

S3). The HS01085340_m1 target, does not include the transmembrane domain and is positioned between two motifs essential for SARS-CoV receptor binding (Figure S3).

\section{Statistical Analysis}

De-identified data reporting participant COVID-19 test result, site of sample collection, type of collection media, accessioning laboratory, age and biological sex was accessed from public health laboratory records. Matching of COVID-19-positive people, who met the described inclusion, exclusion criteria, to COVID-19-negative participants by age and biological sex in a 1:1 ratio was performed by a nearest neighbor algorithm $(n=424) .{ }^{16}$ Bivariate analysis was performed between: age, biological sex, viral RNA load, TMPRSS2, soluble or transmembrane $A C E 2$, and COVID-19 test result. The balance of covariates between test groups was examined post matching.

The relationship between age and nasopharyngeal expression of transmembrane $A C E 2$ was examined in COVID-19-negative participants over the age of 18 by both linear regression and categorization of age into 9-year intervals. Differences in ACE2 expression by age category were tested by analysis of variance.

Differences in mean expression of host genes by COVID-19 diagnosis was further examined by Levene's test for equal variance and a two-tailed, t-test assuming non-equal variance. ${ }^{17}$ Correlation between host gene expression and viral RNA load was analyzed by simple linear regression. Multivariable analysis was performed by multiple linear regression, variable importance was assessed by the partial f-test. ${ }^{18}$ Collinearity was examined by the variable inflation factor with a cut-off of $10 .{ }^{19}$ The common cause criterion was applied to control for measured confounding, effect modification was incorporated when found statistically significant. ${ }^{20}$ All analysis was performed in RStudio version 1.2.5042 using the packages: car, ggsci, tidyverse, dataexplorer, ggpubr, lmtest, publish, forcats, matchit, tableone and effects. ${ }^{21}$

\section{Role of the Funding Source and Data Stewards}

The funder and data stewards played no role in the study design, analysis or interpretation of the results. As such, interpretation of the results does not reflect the views of the funding organization or data stewards. The study was performed as research at the University of British Columbia and British Columbia Centre for Disease Control. 


\section{Results}

233 The analytic dataset contains an age- and biological sex-matched sample of $\mathrm{n}=424$

234 participants tested for COVID-19 in British Columbia from 24/3/2020-9/5/2020 (Figure S1).

235 Participant characteristics are shown in Table 1. The mean age of $n=212$ COVID-19-positive

236 participants was $61 \cdot 6,47 \cdot 6 \%$ were biologically male. In n=212 COVID-19-negative participants,

237 the mean age was $62 \cdot 1,48 \cdot 6 \%$ were biologically male. Bivariate analysis between the examined

238 covariates and diagnosis (COVID-19-negative or -positive) shows balance of age ( $\mathrm{P}=0 \cdot 83)$ and

239 biological sex $(\mathrm{P}=0.92)$ between groups. Viral RNA (E gene $\mathrm{Ct})$ was only detected in COVID-

24019 positive participants, with an average $\mathrm{Ct}$ value of $28 \cdot 2$. Relative expression of transmembrane

241 ACE2, soluble ACE2, and TMPRSS2 statistically differed by COVID-19 test result (Table 1).

Table 1: Structure and Characteristics of Analytic Data Stratified by COVID-19 Test Result ( $n=424)$.

\begin{tabular}{|c|c|c|c|c|c|c|}
\hline \multirow[b]{2}{*}{ Variable Name } & \multirow[b]{2}{*}{ Level } & \multirow[b]{2}{*}{ Total (n) } & \multicolumn{2}{|c|}{ COVID-19 Test Result } & \multirow[b]{2}{*}{ Chi $X^{\wedge} 2$} & \multirow[b]{2}{*}{ T-Test } \\
\hline & & & Negative & Positive & & \\
\hline & .. & 424 & 212 & 212 & .. & .. \\
\hline & .. & & .. & .. & .. & .. \\
\hline Age (mean [SD]) & .. & 424 & $62.2[24.3]$ & $61.7[23.5]$ & .. & 0.83 \\
\hline \multirow[t]{3}{*}{$\operatorname{Sex}(n[\%])$} & .. & .. & .. & .. & 0.92 & .. \\
\hline & Male & 204 & $103[48.6]$ & $101[47.6]$ & .. & .. \\
\hline & Female & 220 & $109[51.4]$ & $111[52.4]$ & .. & .. \\
\hline \multirow[t]{2}{*}{ E Gene Ct (mean [SD]) } & .. & 424 & .. & $28.2[7.18]$ & .. & .. \\
\hline & .. & .. & .. & .. & .. & .. \\
\hline Transmembrane ACE2 (mean [SD]) & .. & 424 & $(0.00)[1.08]$ & $(-0.609)[1.90]$ & .. & $1.2 \mathrm{e}-4$ \\
\hline Soluble ACE2 (mean [SD]) & .. & 424 & $(0.00)[0.625]$ & $(-0.898)[1.47]$ & .. & $<0.0001$ \\
\hline TMPRSS2 Total (mean [SD]) & .. & 424 & $(0.00)[0.797]$ & $(-1.35)[1.60]$ & .. & $<0.0001$ \\
\hline
\end{tabular}

244 Participants who tested negative or positive by COVID-19 were matched by age and biological sex, balance was

245 checked between groups post matching by chi $\mathrm{X}^{\wedge} 2$ or t-test $(\alpha=0 \cdot 05)$. Relative gene expression of ACE2 and

246 TMPRSS2 was normalized to the negative group by the $2^{-\Delta \Delta \mathrm{Ct}}$ method. ${ }^{15}$

Relationship between ACE2 expression and age in COVID-19-negative participants 
251 linear regression $(\mathrm{P}=0 \cdot 076)$. This finding was reproduced when age was categorized into nine252 year intervals $(\mathrm{P}=0 \cdot 092)$ (Figure 1$)$.

253

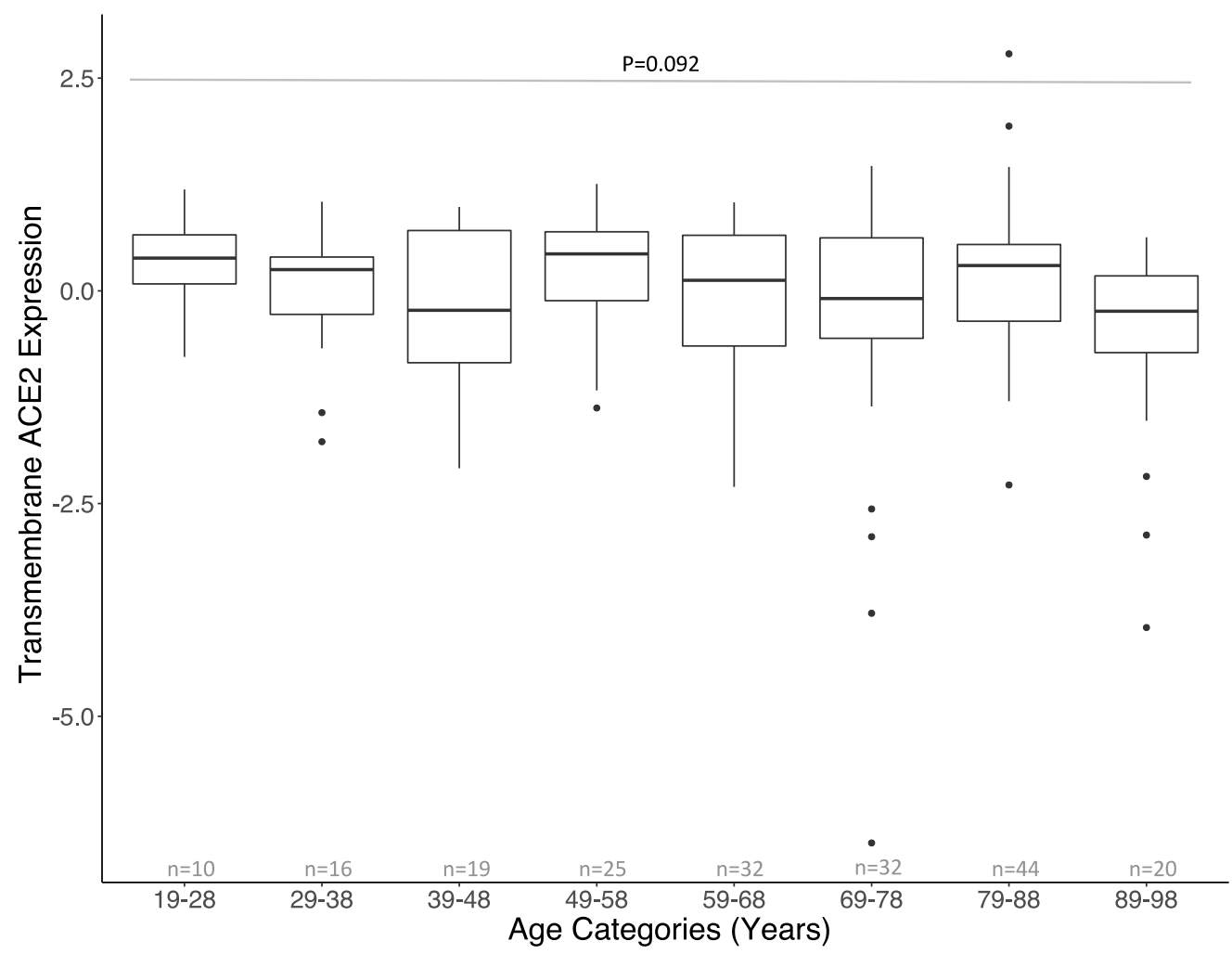

Figure 1: Relationship between age and nasopharyngeal transmembrane ACE2 expression in COVID-19negative participants. Boxplots of transmembrane ACE2 expression by nine-year age categories in COVID-19negative participants between the ages of 19 and 98 ( $n=198)$; boxes represent the Q1-Q3 interquartile range, whiskers represent 1.5x the Q1 or Q3 and horizontal lines the median transmembrane ACE2 expression by age category. Nine-year categories were selected to optimize the distribution of observations between groups.

Participants who tested negative younger than 19 or older than 98 were excluded based on $n<10$ observations per age group. No difference was detected in mean transmembrane ACE2 expression among age categories (ANOVA, $\mathrm{P}=0 \cdot 092)$.

267 These differences were further examined to detect non-equal variance for all host gene targets by

268 COVID-19 test result. Assuming non-equal variance, mean expression differed for transmembrane ACE2 $(\mathrm{P}=1 \cdot 2 \mathrm{e}-4)$, soluble ACE2 $(\mathrm{P}<0 \cdot 0001)$ and TMPRSS2 $(\mathrm{P}<0 \cdot 0001)$ between 
medRxiv preprint doi: https://doi.org/10.1101/2020.11.23.20237206; this version posted November 27, 2020. The copyright holder for this preprint (which was not certified by peer review) is the author/funder, who has granted medRxiv a license to display the preprint in perpetuity.

It is made available under a CC-BY-NC-ND 4.0 International license .

270 those testing COVID-19-negative or -positive (Figure 2). Expression of all three host genes was 271 lower in COVID-19-positive participants.
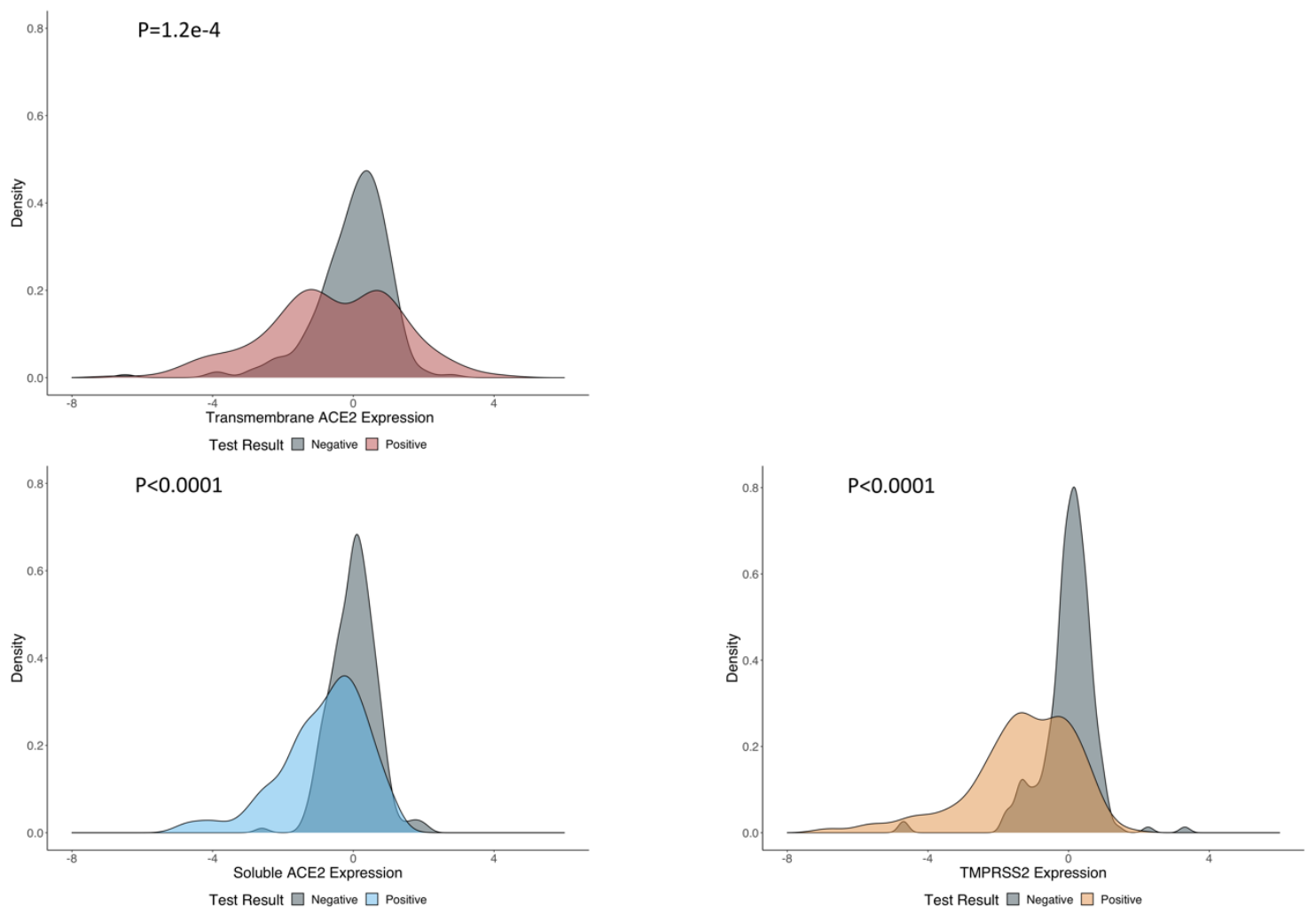

272

Figure 2: Relative nasopharyngeal gene expression of targeted host genes by COVID-19 test result. Gene

274 expression is portrayed in kernel density plots stratified by COVID-19 test result. Probability densities of relative

275 host gene expression are shown by positive (red, transmembrane ACE2; blue, soluble ACE2; yellow, TMPRSS2) and negative COVID-19 test results (grey). Levene's test was used to detect non-equal variance in gene expression for all host targets between COVID-19-negative and -positive participants. A two-tailed, t-test was used to examine mean difference in host gene expression by COVID-19 test result assuming unequal variance: transmembrane ACE2 $(\mathrm{P}=1 \cdot 2 \mathrm{e}-4)$, soluble ACE2 $(\mathrm{P}<0 \cdot 0001)$ and TMPRSS2 $(\mathrm{P}<0 \cdot 0001)$.

Association between host gene expression and viral RNA load in COVID-19-positive participants

Correlations between each host gene and viral RNA load were examined by simple linear regression. Nasopharyngeal expression of transmembrane $A C E 2$ positively correlated with viral

285 RNA ( $\mathrm{P}<0 \cdot 0001)$. Expression of soluble ACE2 negatively correlated with viral RNA 
medRxiv preprint doi: https://doi.org/10.1101/2020.11.23.20237206; this version posted November 27, 2020. The copyright holder for this preprint (which was not certified by peer review) is the author/funder, who has granted medRxiv a license to display the preprint in perpetuity.

It is made available under a CC-BY-NC-ND 4.0 International license .

287 (Figure S2). Multiple linear regression estimated that a one-unit change in transmembrane ACE2

288 expression increases viral RNA load by 0.886 $\log _{10} \mathrm{GE} / \mathrm{mL}$ (95\%CI: 0.596 to 1.18) adjusting

289 for age, biological sex, expression of soluble ACE2 and TMPRSS2 (Table 2). No collinearity was

290 detected between covariates. Biological sex could have been dropped from the model as evident

291 from comparison between nested models ( $\mathrm{P}=0 \cdot 76)$, but was kept for validity. A partial f-test

292 indicated effect modification between transmembrane and soluble $A C E 2$ expression $(\mathrm{P}=0 \cdot 010)$

293 (Table 2). No effect modification was observed between transmembrane expression of ACE2 and

294 TMPRSS2 (P=0·23). High expression of soluble ACE2 decreases viral RNA load (B= -0·0990,

295 95\%CI: [-0.176 to -0.0224]) (Table 2). The association between transmembrane ACE2

296 expression and viral RNA in nasopharyngeal tissue differs by the concomitant level of soluble

297 ACE2 expressed (Figure 3). Effect modification was visualized by categorizing soluble ACE2 by

298 the relative mean expression $+/-2$ standard deviations of all study participants $(\mathrm{Low}=-2 \cdot 86$,

299 Mean $=-0 \cdot 444$, High $=1 \cdot 98, \mathrm{SD}=2 \cdot 43)($ Figure 3). 
medRxiv preprint doi: https://doi.org/10.1101/2020.11.23.20237206; this version posted November 27, 2020. The copyright holder for this preprint (which was not certified by peer review) is the author/funder, who has granted medRxiv a license to display the preprint in perpetuity. It is made available under a CC-BY-NC-ND 4.0 International license.

318 Table 2: Unadjusted, Adjusted and Effect Modification Linear Regression Models of SARS-CoV-2 Viral

319 RNA Load

\begin{tabular}{|c|c|c|c|}
\hline Variables & Unadjusted, $B(95 \% \mathrm{CI})$ & Adjusted, B(95\% CI) & Effect Modification, $B(95 \% \mathrm{CI})$ \\
\hline Intercept ${ }^{a}$ & $5.44(5.12$ to 5.77$)$ & $2.55(1.71$ to 3.40$)$ & $2.48(1.65$ to 3.31$)$ \\
\hline $\begin{array}{l}\text { Transmembrane ACE2 } \\
\text { Expression }^{\mathrm{b}}\end{array}$ & 0.493 (0.329 to 0.656$)$ & $0.886(0.596$ to 1.18$)$ & $0.624(0.274$ to 0.975$)$ \\
\hline Soluble ACE2 Expression ${ }^{c}$ & -- & $-0.243(-0.494$ to 0.00834$)$ & $-0.484(-0.794$ to -0.174$)$ \\
\hline TMPRSS2 Expression ${ }^{\mathrm{d}}$ & -- & $-0.873(-1.21$ to -0.533$)$ & $-0.713(-1.07$ to -0.336$)$ \\
\hline $\operatorname{Age}^{\mathrm{e}}$ & -- & $0.0276(0.0162$ to 0.0389$)$ & $0.0259(0.0146$ to 0.0372$)$ \\
\hline Biological Sex ${ }^{f}$ & -- & $0.0778(-0.424$ to 0.579$)$ & $0.0735(-0.422$ to 0.569$)$ \\
\hline $\begin{array}{l}\text { Transmembrane ACE2* Soluble ACE2 } \\
\text { Expression }{ }^{\mathrm{g}}\end{array}$ & -- & -- & $-0.0990(-0.176$ to -0.0224$)$ \\
\hline
\end{tabular}

322 a Viral RNA load in females, measured by $\log _{10}$ viral genome equivalents per millilitre $\left(\log _{10} \mathrm{GE} / \mathrm{mL}\right)$ targeting the 323 SARS-CoV-2 E gene.

$324{ }^{\mathrm{b}}$ Transmembrane ACE2 Expression $\left(2^{-\triangle \Delta C t}\right)$ in the nasopharyngeal epithelium of SARS-CoV-2 positive participants.

$325{ }^{\mathrm{c}}$ Soluble $A C E 2$ expression $\left(2^{-\Delta \Delta C t}\right)$ in the nasopharyngeal epithelium of SARS-CoV-2 positive participants.

$326{ }^{\mathrm{d}}$ TMPRSS2 expression $\left(2^{-\Delta \Delta \mathrm{Ct}}\right)$ in the nasopharyngeal epithelium of SARS-CoV-2 positive participants.

327 e Age, measured in years.

$328{ }^{\mathrm{f}}$ Biological sex, effect of being male.

$329 \mathrm{~g}$ Effect modification term, the effect of transmembrane ACE2 expression on viral RNA load differs by expression of 330 soluble ACE2. 


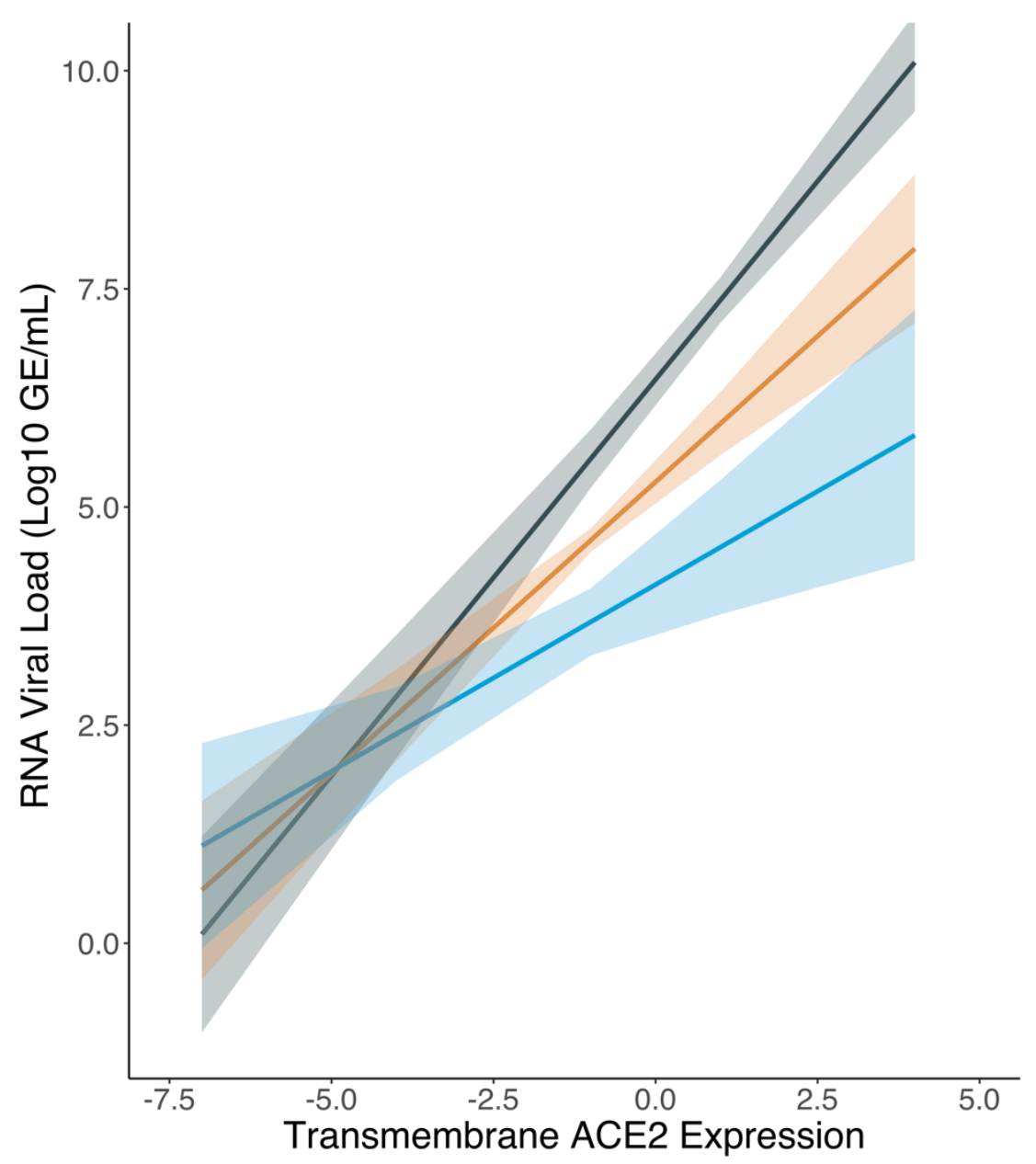

\section{Soluble ACE2 Expression}

- $\operatorname{Low}(-2 S D)$

- Mean (OSD)

- High (+2SD)

Figure 3: The association between transmembrane $A C E 2$ expression and SARS-CoV-2 RNA load in nasopharyngeal tissue differs by the amount of soluble $A C E 2$ expression. Soluble ACE2 expression was categorized into low, mean and high levels to demonstrate the relationship. The low category (grey) represents soluble ACE2 expression two standard deviations below the mean expression. The mean category (orange) codes for the mean soluble $A C E 2$ expression, zero standard deviations. The high category (blue) indicates soluble ACE2 expression two standard deviations above mean expression. Shaded areas represent $95 \%$ confidence intervals, solid lines represent $B$ coefficients from multiple linear regression.

\section{Discussion}

In the described study, we measured nasopharyngeal ACE2 and TMPRRS2 relative gene

345 in British Columbia. Analysis was performed to understand: the relationship between ACE2

346 expression and age in COVID-19-negative participants, differences in host gene expression

347 between COVID-19-negative and -positive participants and the role of ACE2 in SARS-CoV-2 
infection in those who tested positive for COVID-19.

Among participants tested negative for COVID-19, we found no relationship between nasopharyngeal ACE2 expression and age, in a group of adults between 19-98 years of age. This result, agrees with findings from other efforts to characterize nasopharyngeal ACE2 expression at the population level. Bunyavanich et al. reported a difference in ACE2 expression levels between children younger than ten years old and young adults from eighteen to twenty-four years old. ${ }^{22}$ No difference was evident between young adults, and adults twenty-five or more years in age. ${ }^{22}$ Lack of a relationship between nasopharyngeal $A C E 2$ expression and progressive aging suggests that expression of $A C E 2$ in the upper airway does not correlate with expression of $A C E 2$ in the RAAS. The physiological importance of ACE2 in the RAAS suggests that its expression would increase in response to age as older people have higher prevalence of cardiovascular disease or similar comorbidities (i.e. diabetes). ${ }^{23}$ If nasopharyngeal expression of ACE2 occurs independently of the RAAS pathway, future studies should ascertain what factors if any regulate expression of soluble $A C E 2$ in nasopharyngeal tissue and variation of $A C E 2$ expression in COVID-19-negative people over time. Some populations, such as young children, may have differential levels of nasopharyngeal ACE2 expression which protect against SARS-CoV-2 viral infection. ${ }^{22,24}$

Participants who tested positive for COVID-19 were matched to those who tested negative by age and biological sex to estimate the direct relationship between host gene expression and SARS-CoV-2 test result. This analysis demonstrated that mean expression of transmembrane, soluble ACE2 and TMPRSS2 decreased in COVID-19-positive participants, while variation increased. Unfortunately, the limitation of reverse-causality in cross-sectional study design prevents us from understanding whether the presence of SARS-CoV-2 in positive samples affects host gene expression or host gene expression puts people at risk of viral infection. However, if we make the plausible assumption that at least a single round of viral replication must occur in order for qRT-PCR to generate a positive test result, it suggests that the observed variation in host gene expression of participants who test positive for COVID-19 results from viral replication. ${ }^{25}$ Numerous studies have demonstrated that coronavirus replication disrupts cellular transcription, as resources required by the cell to produce mRNA are instead sequestered by virus to replicate its genome. ${ }^{26}$ Reduced transcription of $A C E 2$ by SARS-CoV, but not HCoV-NL63, in an in vitro model of Vero E6 cell infection was previously 
suggested as a pathological mechanism. ${ }^{3}$ Putative SARS-CoV-2 disruption of ACE2 expression could partially explain the apparent association between hypertension, diabetes, and severe COVID-19. ${ }^{27}$ Answering these questions; however, requires a longitudinal study design to test the temporal effect of SARS-CoV-2 replication on the expression of ACE2 and other implicated 383 host genes.

The sample was then restricted to participants who tested positive for COVID-19 to investigate the association between nasopharyngeal ACE2 expression and SARS-CoV-2 RNA load. Bivariate and multivariable analysis both suggest that $A C E 2$ plays a dual, contrasting role in SARS-CoV-2 infection. Transmembrane ACE2 positively correlates with viral RNA load, while soluble ACE2 may limit viral infection by reducing viral RNA load. Interestingly, effect modification was observed between transmembrane and soluble $A C E 2$ implicating that the proportion between these molecules may have more importance than absolute expression of

391 either individually. For example, between two people with similar above-average

392 nasopharyngeal transmembrane ACE2 expression, we would expect a higher viral RNA load in 393 the one with lower soluble ACE2 expression. Though we are not equipped to characterize the 394 mechanism by which soluble ACE2 plays a protective role in SARS-CoV-2 infection, 395 identification of this effect at the population level warrants further investigation of the 396 underlying mechanism. Previous work has postulated that soluble ACE2 restricts SARS-

397 CoV/SARS-CoV-2 infection by acting as a decoy substrate. ${ }^{28}$ In a study of virus-ACE2 dynamics 398 in engineered human tissue, instead of binding to transmembrane $A C E 2$, virus particles bound to 399 soluble ACE2 and were unable to infect susceptible cells. ${ }^{28}$ Moreover, recombinant soluble 400 ACE2 was recently administered to a COVID-19 patient requiring ventilation. ${ }^{8}$ In the case report, 401 administration of soluble ACE2 decreased viral RNA load in the patient's plasma, tracheal 402 aspirate and nasopharyngeal specimens. Additionally, soluble ACE2 did not interfere with 403 production of $\mathrm{IgG}$ and assumed its cardiovascular protective role in the RAAS. ${ }^{8}$

404 Soluble ACE2 may also influence the usage of Neuropilin-1 as a co-receptor or 405 alternative receptor for SARS-CoV-2. Function of Neuropilin-1 for cell entry and infectivity may 406 depend upon high SARS-CoV-2 viral load; therefore, expression of soluble ACE2 may limit 407 SARS-CoV-2 tropism. ${ }^{29}$

408 We acknowledge that the described study has several limitations. In our sample, the age 409 distribution possesses a left skew which prevents us from examining the relationship between 
410 age and nasopharyngeal expression of $A C E 2$ in participants younger than 18 years of age. The

411 difference in mean host gene expression observed between participants who tested negative or

412 positive for COVID-19 cannot be resolved in a cross-sectional study design due to reverse

413 causality. We attempted to control for immunological gene regulation by excluding people with

414 endemic respiratory co-infections from Influenza A/B or Respiratory syncytia virus. We describe

415 associations between transmembrane, soluble ACE2 and SARS-CoV-2 RNA load which suggest

416 the dual, contrasting role of ACE2 in viral infection. However, we cannot provide evidence of the

417 mechanism responsible for this association. Additionally, the measure of viral RNA load over-

418 approximates infectious viral titre and viral RNA may be isolated in the absence of infectious

419 virus. $^{30}$

420 In conclusion, we have characterized nasopharyngeal ACE2 expression in a sample of 421 people tested for COVID-19. Analysis shows no relationship between age and nasopharyngeal

422 ACE2 expression in COVID-19-negative participants 19-98 years old. Expression of

423 nasopharyngeal ACE2 and TMPRSS2 differs between COVID-19-positive and -negative groups.

424 The role of nasopharyngeal ACE2 in SARS-CoV-2 infection of the upper-airway may be

425 differentiated by gene isoform expression; transmembrane ACE2 positively correlates with viral

426 RNA load, while soluble ACE2 shows a negative association. Nasopharyngeal expression of

427 ACE2 possesses a dual, contrasting role in SARS-CoV-2 infection at the population level.

429 Contributors

430 AMN, DDWT, KSK, NAP, ANJ, MK, DMP, and IS conceived, designed, and obtained funding

431 for the project. AMN wrote the manuscript, editing was provided by Karen Chu. AMN, DDWT

432 and KSK performed the experiments. CDL and HS obtained and cleaned laboratory data. AMN,

433 KSK, DDWT, CAB, CDL, and HS analyzed the data under the direction of CS, NAP, ANJ, MK,

434 DMP and IS. All authors interpreted the data, edited the manuscript and provided their approval 435 to publish. 
medRxiv preprint doi: https://doi.org/10.1101/2020.11.23.20237206; this version posted November 27, 2020. The copyright holder for this preprint (which was not certified by peer review) is the author/funder, who has granted medRxiv a license to display the preprint in perpetuity.

It is made available under a CC-BY-NC-ND 4.0 International license .

\section{Declaration of Interests}

438 The authors have no conflicts of interest to declare.

440 Acknowledgments

441 We would like to acknowledge the work of all our clinical colleagues at the British

442 Columbia Centre for Disease Control and across the globe in responding to the COVID-19

443 pandemic. This work would not have been possible without funding from Genome British

444 Columbia. We would like to thank Michael Donoghue for managing this multi-stakeholder

445 project and Karen Chu for assisting as a medical copy editor.

447 References

4491 Zhu N, Zhang D, Wang W, et al. A Novel Coronavirus from Patients with Pneumonia in $450 \quad$ China, 2019. N Engl J Med 2020; 382: 727-33.

4512 Hoffmann M, Kleine-Weber H, Schroeder S, et al. SARS-CoV-2 Cell Entry Depends on 452 ACE2 and TMPRSS2 and Is Blocked by a Clinically Proven Protease Inhibitor. Cell 2020; 453 181: 271-280.e8.

4543 Glowacka I, Bertram S, Herzog P, et al. Differential Downregulation of ACE2 by the 455 Spike Proteins of Severe Acute Respiratory Syndrome Coronavirus and Human 456 Coronavirus NL63. J Virol 2010; 84: 1198-205.

4574 South AM, Diz DI, Chappell MC. COVID-19, ACE2, and the cardiovascular $458 \quad$ consequences. Am J Physiol Circ Physiol 2020; 318: H1084-90.

4595 Sungnak W, Huang N, Bécavin C, et al. SARS-CoV-2 entry factors are highly expressed 460 in nasal epithelial cells together with innate immune genes. Nat Med 2020; 26: 681-7.

4616 Harmer D, Gilbert M, Borman R, Clark KL. Quantitative mRNA expression profiling of 462 ACE 2, a novel homologue of angiotensin converting enzyme. FEBS Lett 2002; 532: 107463 10.

4647 Yan R, Zhang Y, Li Y, Xia L, Guo Y, Zhou Q. Structural basis for the recognition of 
medRxiv preprint doi: https://doi.org/10.1101/2020.11.23.20237206; this version posted November 27, 2020. The copyright holder for this preprint (which was not certified by peer review) is the author/funder, who has granted medRxiv a license to display the preprint in perpetuity.

It is made available under a CC-BY-NC-ND 4.0 International license .

SARS-CoV-2 by full-length human ACE2. Science (80- ) 2020; 367: 1444-8.

Zoufaly A, Poglitsch M, Aberle JH, et al. Human recombinant soluble ACE2 in severe COVID-19. Lancet Respir Med 2020; published online Sept. DOI:10.1016/S22132600(20)30418-5.

9 Corman VM, Landt O, Kaiser M, et al. Detection of 2019 novel coronavirus (2019-nCoV) by real-time RT-PCR. Eurosurveillance 2020; 25. DOI:10.2807/15607917.ES.2020.25.3.2000045.

10 Messmann R, Dietl A, Wagner S, et al. Alterations of the renin angiotensin system in human end-stage heart failure before and after mechanical cardiac unloading by LVAD support. Mol Cell Biochem 2020; 472: 79-94.

11 Kitajima T, Okita Y, Kawamura M, et al. The relationship between preoperative T helper cytokines in the ileal mucosa and the pathogenesis of pouchitis. BMC Gastroenterol 2020; 20: 277.

12 Shirato K, Kawase M, Matsuyama S. Wild-type human coronaviruses prefer cell-surface TMPRSS2 to endosomal cathepsins for cell entry. Virology 2018; 517: 9-15.

13 Hologic. Instructions for Using the Aptima Swab Specimen Collection Kit for PatientCollected Specimens. 2020.

4 LeBlanc JJ, Gubbay JB, Li Y, et al. Real-time PCR-based SARS-CoV-2 detection in Canadian laboratories. J Clin Virol 2020; 128: 104433.

15 Livak KJ, Schmittgen TD. Analysis of Relative Gene Expression Data Using Real-Time Quantitative PCR and the 2- $\Delta \Delta$ CT Method. Methods 2001; 25: 402-8.

6 Ho DE, Imai K, King G, Stuart EA. MatchIt : Nonparametric Preprocessing for Parametric Causal Inference. J Stat Softw 2011; 42. DOI:10.18637/jss.v042.i08.

17 Gastwirth JL, Gel YR, Miao W. The Impact of Levene's Test of Equality of Variances on Statistical Theory and Practice. Stat Sci 2009; 24: 343-60.

8 Jamshidian M, Jennrich RI, Liu W. A study of partial F tests for multiple linear regression models. Comput Stat Data Anal 2007; 51: 6269-84.

9 Fox J, Monette G. Generalized Collinearity Diagnostics. J Am Stat Assoc 1992; 87: 178.

20 VanderWeele TJ. Principles of confounder selection. Eur J Epidemiol 2019; 34: 211-9. Rstudio Team. RStudio. 2019.

Bunyavanich S, Do A, Vicencio A. Nasal Gene Expression of Angiotensin-Converting 
medRxiv preprint doi: https://doi.org/10.1101/2020.11.23.20237206; this version posted November 27, 2020. The copyright holder for this preprint (which was not certified by peer review) is the author/funder, who has granted medRxiv a license to display the preprint in perpetuity.

It is made available under a CC-BY-NC-ND 4.0 International license .

Enzyme 2 in Children and Adults. JAMA 2020; published online May 20. DOI:10.1001/jama.2020.8707.

23 Ni W, Yang X, Yang D, et al. Role of angiotensin-converting enzyme 2 (ACE2) in COVID-19. Crit Care 2020; 24: 422.

24 Dong Y, Mo X, Hu Y, et al. Epidemiology of COVID-19 Among Children in China. Pediatrics 2020; 145: e20200702.

25 Bar-On YM, Flamholz A, Phillips R, Milo R. SARS-CoV-2 (COVID-19) by the numbers. Elife 2020; 9. DOI:10.7554/eLife.57309.

26 Nakagawa K, Lokugamage KG, Makino S. Viral and Cellular mRNA Translation in Coronavirus-Infected Cells. 2016: 165-92.

27 Obukhov AG, Stevens BR, Prasad R, et al. SARS-CoV-2 Infections and ACE2: Clinical Outcomes Linked With Increased Morbidity and Mortality in Individuals With Diabetes. Diabetes 2020; 69: 1875-86.

28 Monteil V, Kwon H, Prado P, et al. Inhibition of SARS-CoV-2 Infections in Engineered Human Tissues Using Clinical-Grade Soluble Human ACE2. Cell 2020; 181: 905-913.e7.

29 Cantuti-Castelvetri L, Ojha R, Pedro LD, et al. Neuropilin-1 facilitates SARS-CoV-2 cell entry and infectivity. Science (80- ) 2020; : eabd2985.

30 Bullard J, Dust K, Funk D, et al. Predicting Infectious Severe Acute Respiratory Syndrome Coronavirus 2 From Diagnostic Samples. Clin Infect Dis 2020; published online May 22. DOI:10.1093/cid/ciaa638. 


All Available People
Merged Public Health
Laboratory Data From:
$24 / 3 / 2020-9 / 5 / 2020$
$\mathrm{n}=25,959$

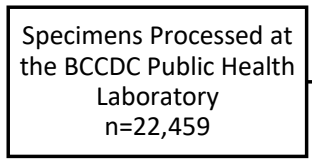

Primary Specimens by Provincial Health Number $n=16,095$

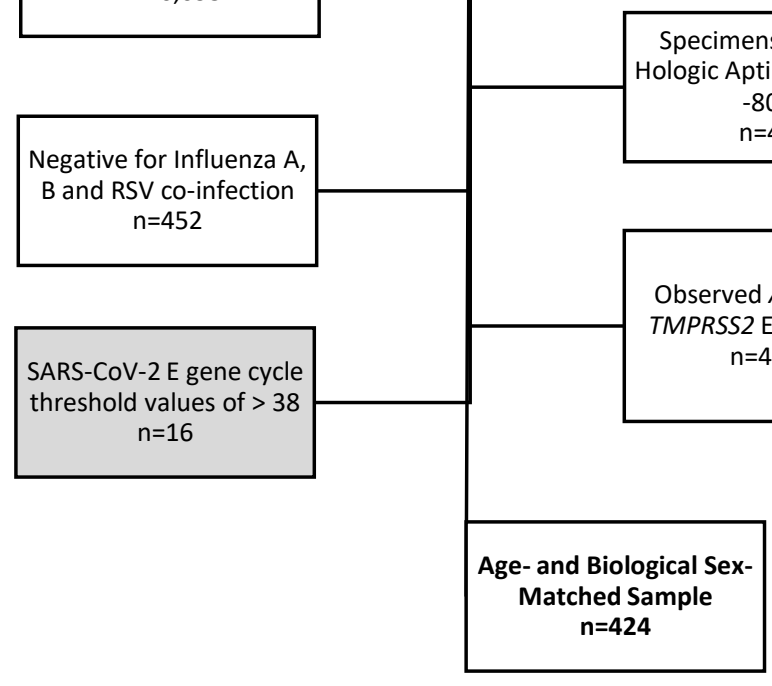

Study Participants
Specimens Collected by Nasopharyngeal Swab $n=18,275$

Observed ACE2 and $\mathrm{n}=444$

Figure S1: Inclusion, exclusion criteria applied to all people tested for COVID-19 in British tested for COVID-19 with the following criteria were included (white box): tested at the BCCDC-PHL, specimen was collected by nasopharyngeal swab, test was the primary test by provincial health number, specimen was suspended in Hologic Aptima ${ }^{\mathrm{TM}}$ media and stored at $-80^{\circ} \mathrm{C}$ following testing, negative for Influenza A, B or Respiratory syncytia virus infection and possessing host gene expression data. Those with a COVID-19-positive diagnosis, were further restricted by excluding (grey box) SARS-CoV-2 E gene Ct values of $>38$ by qRT-PCR $(n=212)$, and matched in a 1:1 ratio with COVID-19-negative people $(n=212)$ by age and biological sex (bold text). 

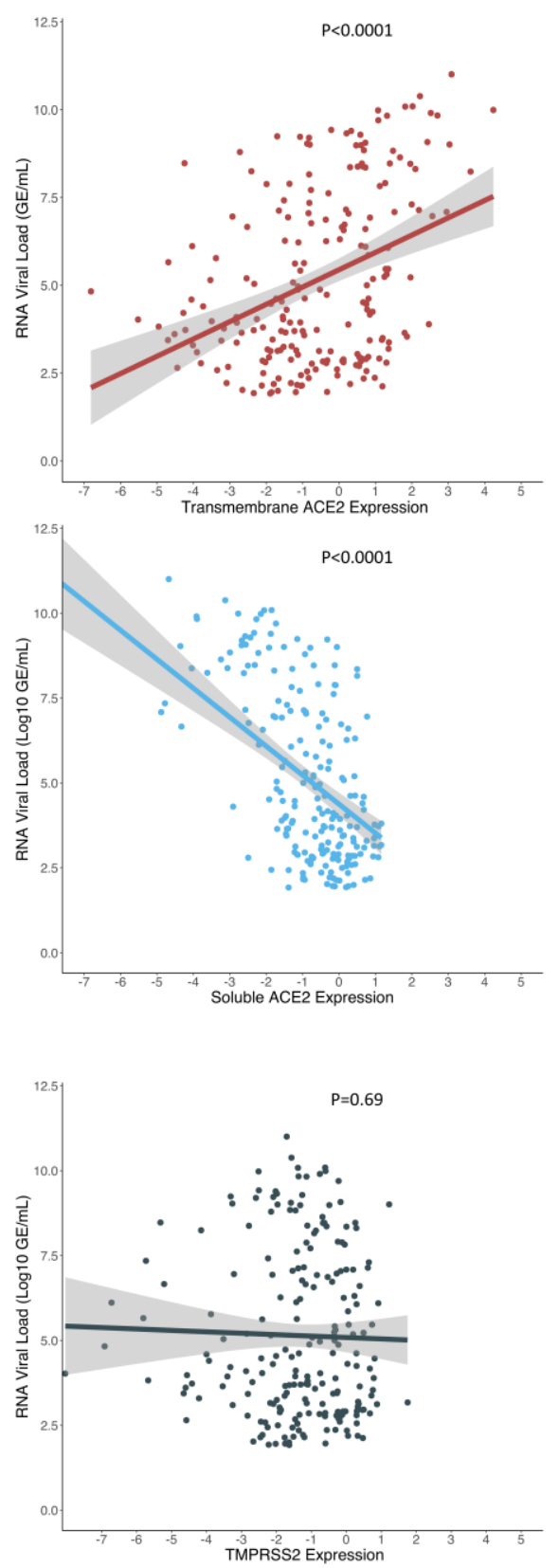

542 Figure S2: Correlation between host gene expression in COVID-19-positive participants and SARS-CoV-2

543 RNA load. The level of transmembrane ACE2 (red), soluble ACE2 (blue) and TMPRSS2 (black) expression in 544 positive cases of COVID-19 and its relationship with SARS-CoV-2 RNA is shown in $\log _{10}$ genome equivalents per 545 millilitre $(\mathrm{GE} / \mathrm{mL})$. Host gene expression was measured by quantitative real-time PCR and normalized to expression

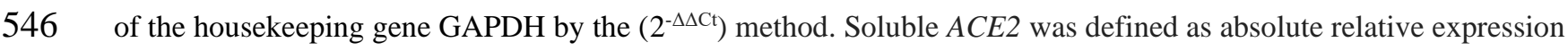
547 between the Hs01085333_m1 (ThermoFisher) and HS01085340_m1 (ThermoFisher) gene targets (Figure S3). 
medRxiv preprint doi: https://doi.org/10.1101/2020.11.23.20237206; this version posted November 27, 2020. The copyright holder for this preprint (which was not certified by peer review) is the author/funder, who has granted medRxiv a license to display the preprint in perpetuity.

It is made available under a CC-BY-NC-ND 4.0 International license .

548 Simple linear regression was used estimate correlations, the reported $\mathrm{P}$ values are for the Beta-coefficients of host

549 gene expression.

550

551 Table S1: Serial Dilution of SARS-CoV-2 RNA for Generation of a Standard Curve by Quantitative Real-

552 Time Polymerase Chain Reaction.

\begin{tabular}{|c|c|c|c|c|c|}
\hline $\log _{10}$ Dilution & $10^{\wedge} 0$ & $10^{\wedge} 1$ & $10^{\wedge} 2$ & $10^{\wedge} 3$ & $10^{\wedge} 4$ \\
\hline$\sim \mathrm{GE} / \mathbf{m L}^{\tau}$ & 1 & 10 & 100 & 1000 & 10,000 \\
\hline $\mathbf{R} 1$ & 36.1 & 32.6 & 28.9 & 25.9 & 22.8 \\
\hline $\mathbf{R 2}$ & 35.8 & 31.9 & 28.8 & 25.8 & 22.8 \\
\hline $\mathbf{R 3}$ & 34.8 & 32.3 & 28.8 & 25.8 & 22.8 \\
\hline R4 & 35.6 & 31.7 & 28.8 & 25.7 & 22.8 \\
\hline R5 & 34.5 & 31.9 & 28.6 & 25.7 & 22.3 \\
\hline R6 & 34.0 & 32.1 & 28.7 & 25.5 & 22.7 \\
\hline R7 & 34.4 & 31.9 & 28.6 & 25.6 & 22.8 \\
\hline R8 & 34.1 & 31.4 & 28.8 & 25.6 & 22.8 \\
\hline R9 & 34.7 & 31.4 & 28.7 & 25.6 & 22.9 \\
\hline
\end{tabular}

553 a 5-fold, 1:10 serial dilution of SARS-CoV-2 synthetic RNA was performed over nine independent replicates $(\mathrm{n}=9)$

554 to measure a standard curve by quantitative real-time PCR targeting the viral E gene.

$555{ }^{\tau}$ a simple linear regression model was fit to $\mathrm{n}=9$ replicates of the SARS-CoV-2 RNA standard curve: $\mathrm{GE} / \mathrm{mL}=\mathrm{b}_{0}+$ $556 b_{1} \mathrm{x}_{1}$. Where, Genome Equivalents per millilitre $(\mathrm{GE} / \mathrm{mL})=34.5-1.27 \ln (\mathrm{x})$ and $\mathrm{R}^{\wedge} 2=0.999$. 
medRxiv preprint doi: https://doi.org/10.1101/2020.11.23.20237206; this version posted November 27, 2020. The copyright holder for this preprint (which was not certified by peer review) is the author/funder, who has granted medRxiv a license to display the preprint in perpetuity.

It is made available under a CC-BY-NC-ND 4.0 International license .

\begin{abstract}
Homo sapiens angiotensin I converting enzyme 2 (ACE2), transcript variant 2, mRNA NCBI Reference Sequence: NM_021804.3
\end{abstract}

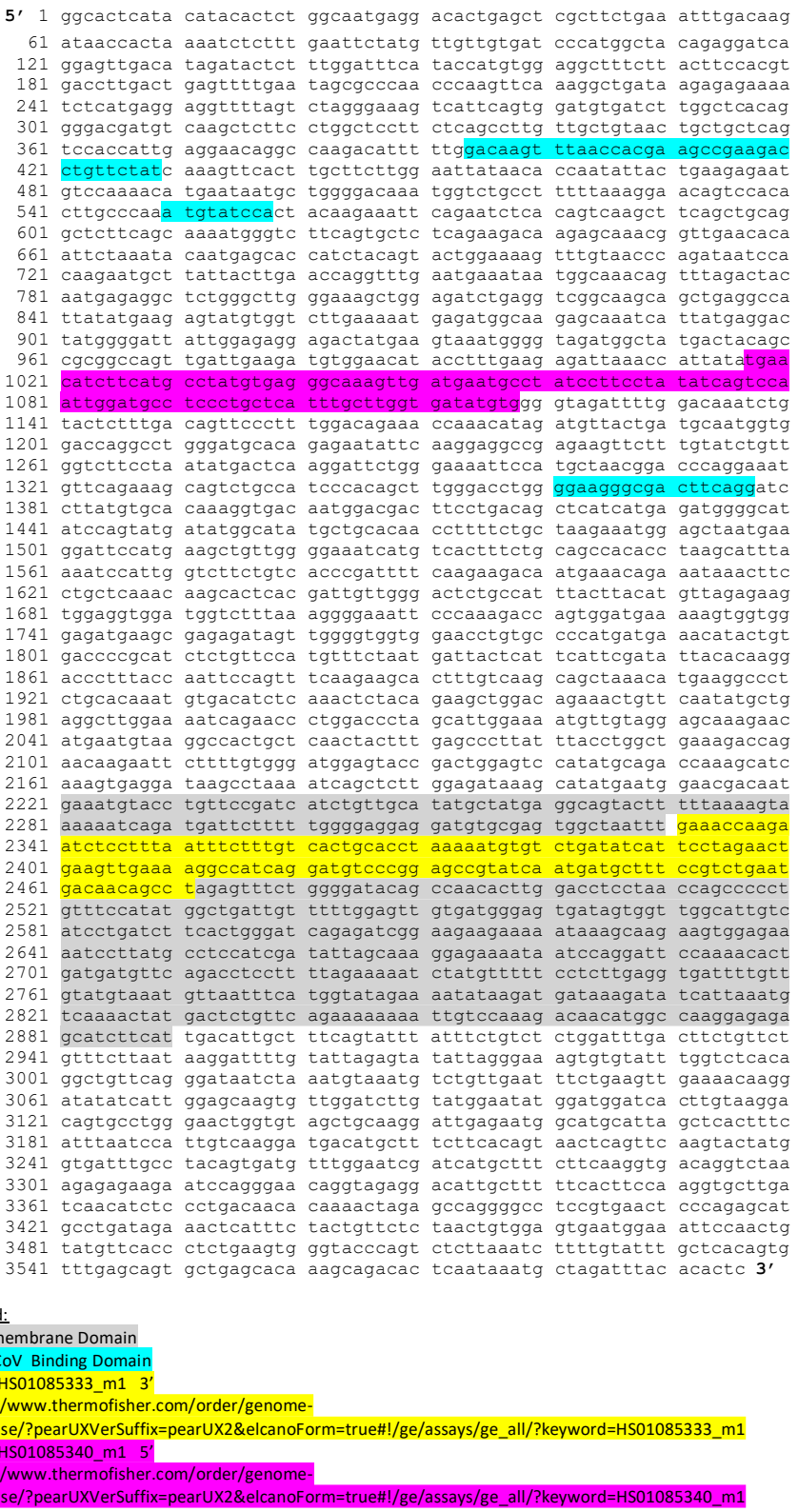

560 Figure S3: Nasopharyngeal expression of $A C E 2$ was determined by two quantitative real-time polymerase

561 chain reaction targets, one target (yellow) exon spans the $A C E 2$ transmembrane domain. The other does not

562 include the transmembrane domain (pink) and lays nested between two motifs known to interact with the SARS-

$563 \mathrm{CoV}$ receptor binding domain (blue). The measure of soluble ACE2 represents normalized expression of the pink to

564 yellow target, or the proportion of non-transmembrane ACE2 to transmembrane ACE2. 